\title{
Epidemiological investigation of Paramphistomiasis in cattle at selected areas of Sirajgonj district of Bangladesh
}

\author{
A. K. Paul ${ }^{1}$, M. Talukder ${ }^{2}$, K. Begum ${ }^{3}$ and M. A. Rahman ${ }^{1}$ \\ ${ }^{1}$ Department of Medicine and Surgery, ${ }^{2}$ Department of Physiology, Biochemistry and Pharmacology and ${ }^{3}$ Depatment \\ of Basic Science, Faculty of Animal Science and Veterinary Medicine, Patuakhali Science and Technology University, \\ Patuakhali, Bangladesh. E-mail: akpaul2008@gmail.com
}

\begin{abstract}
To investigate the Epidemiology of Paramphistomum infection in cattle, faecal samples from 360 cattle were collected from individual areas of the Sirajgonj district from March 2009 to April 2010. One hundred and ninety one animals (53.1\%) were infected with single or multiple species of Paramphistomum. Age of animals significantly $(P<0.05)$ influenced the prevalence of Paramphistomiasis. Older animals suffered (60.3\%) more than growing (44.4\%) and young (54.0\%) ones. Older animals were 1.94 times more susceptible than growing animals. Furthermore, females were more (59.5\%; 1.79 times) susceptible to Paramphistamum spp. than males (45\%). Breed has also significant $(p<0.05)$ effect. The prevalence of Paramphistomiasis was higher $(p<0.05)$ in crossbred $(61.8 \%)$ animals than that of local (49.2\%) cattle. The crossbreed cattle were 1.7 times more susceptible than indigenous cattle. The prevalence of Paramphistomiasis in cattle varied $(p<0.05)$ depending on the season of the year; being highest in the rainy season $(60.8 \%)$ followed by the summer $(50 \%)$ and lowest during the winter $(48.3 \%)$. A high percentage of paramphistomiasis was recorded in the cattle studied during the winter irrespective of age and genetics of animals and seasons of the year.
\end{abstract}

Keywords: Cattle breeds, Paramphistomiasis, Prevalence, Sirajgonj

\section{Introduction}

In Bangladesh, there are many constrains in cattle production, among them malnutrition and parasitism are the major limiting factors (Jabber and Green, 1983). The losses due to parasitism take in the form of mortality, lower general health condition, retarded growth, decrease in the production of milk and meat and lower output of work (Faiz, 1972). The geo-climatic conditions together with the water-logged and low-lying areas in Bangladesh are conducive to parasitic diseases in domestic ruminants. Infact, cattle of Bangladesh are affected by various types of helminth parasites (Rahman and Razzak, 1973; Rahaman and Mondal, 1983). Experts from both government and non-government organization in Bangladesh believe that parasitic diseases are of enormous economic importance (Islam, 1985). In ruminants, paramphistomiasis is often associated with diarrhea, loss of body condition, rough hair coat, dullness, weakness, loss of appetite, intestinal haemorrhages, anemia, reduced milk production and intermandibular swelling (Chandrasekharan et al., 1982). The flukes is widespread in Bangladesh (Hosain and Baki, 1987; Rabbani, 1992 ; Saifuzzaman, 1996). Afazuddin (1985) estimated an annual economic loss of about $1400 \$$ due to various parasitic diseases in cattle in military farm, Savar, Dhaka. The paramphistomum is normally present in cattle gastro-intestinal tract but over loading has an adverse effect. However, the epidemiological study of Paramphistomiasis has not yet been investigated properly in cattle at the char areas of Sirajgonj district in Bangladesh. The aim of present investigation was to study the prevalence of Paramphistomiasis in cattle in Sirajgonj District of Bangladesh.

\section{Materials and Methods}

Faecal samples from 120 cattle were collected from selected areas of the Sirajgonj district during a period from March 2009 to April. Morphological examination of eggs was conducted in Upazilla Livestock office, Kazipur.

Cattle at 6 months or older age were selected. The age of the animal were determined by observing teeth eruption and taking history from owner. During collection of samples data on the age, sex, breed, place of farming and season of the year carefully recorded. The cattle were grouped into three groups: Growing animals (6 months- 2 years); Young animals (> 2- 5 years); older animals (> 5 years). 
Faecal samples were collected directly from the rectum and also from recently voided faeces of 360 cattle in every season summer (March to June), rainy (July to October) and winter (November to February) from different villages of the Sirajgonj district. Collected samples were taken in small polythene bag which were identified properly as per age, sex and breed of the animals. The samples were transferred to Upazilla Livestock office, Kazipur and within 1-3 hours following the method described by Solusby (1982).

\section{Technique of total egg count per gram of feces (EPG) (Solusby 1982)}

The fecal sample was first well mixed and then $3 \mathrm{gm}$ were weighed and put in $100 \mathrm{ml}$ beaker containing $45 \mathrm{ml}$ of water. Some glass beads were added. The feces were thoroughly mixed with a magnetic stirrer. The mixture was strained through a coffee strainer. The strained mixture was again shaken and $0.15 \mathrm{ml}$ of the mixture was taken with a $1 \mathrm{ml}$ syringe and put on a slide and covered with a cover slip. The slide was then placed under a microscope and the Paramphistomum eggs were identified on the basis of their characteristics morphological features as described by Soulsby (1982) and then counted. The counted total number of eggs found in one slide was multiplied by 100 to get the EPG. (Egg per gram feces).

Statistical analysis: The influence of considered factors on the prevalence of paramphistomiasis, were analyzed by logistic regreesion. The regression was done following the methods described by Mostafa (1989) by using SPSS (Version 11.5) software.

\section{Results and Discussion}

Prevalence of Paramphistomosis: Details of the prevalence of Paramphistomiasis in cattle of the selected areas of the Sirajgonj district with regards to age, sex, and breed of animals and feeding system in three seasons are shown in the Table 1 . The present investigation revealed a high percentage of Paramphistomiasis (53.1\% in faecal sample) in cattle in sirajgonj area. However, faecal examination of cattle and buffaloes from some limited areas of Bangladesh have also suggested that the prevalence of Paramphistomiasis is very much common in Bangladesh. (Afazuddin, 1985; Rahman and Mondal, 1983; Rabbani, 1992 and Saifuzzaman, 1996). The overall Prevelence of Paramphistomiasis recorded in cattle was very similar with, Saifuzzaman (1996), 52.2\%; Sahay et al. (1989), 58.3\% and slightly lower than the reports of Rahman \& Razzak (1973), 62.6\%; and higher than the repots of Rahman and Mondal (1983), 21.6\%; Islam \& Samad (1989), 46.3\%. This variation in the prevalence of Paramphistomiasis in cattle may be due to agro ecological conditions, animal husbandry practices and breeds of animal.

Effects of breed on paramphistomiasis: The prevalence of Paramphistomiasis was higher in crossbred cattle (61.8\%) than that in indigenous cattle (49.2\%). The difference between breeds was significant $(\mathrm{P}<0.05)$. The higher prevalence of Paramphistomiasis in crossbred cattle may be due to their lower resistance to tropical diseases than indigenous animals.

Effects of age of the cattle on paramphistomiasis: The prevalence of Paramphistomiasis varrried depending on their age in cattle (Table $1 ; \mathrm{P}<0.05)$. Highest rate of infection was found in the older cattle (60.3\%). The lower rate of infection was found in the young animals (54.0\%) and the lowest rate of infection was recorded in the growing calves (44.4\%). This result is in agreement with the earlier findings of Okafor et al. (1988) who reported that there was an age limit in the prevalence of Paramphistomiasis. They also reported that heavy infection was found in cattle more than five years of age. The reason for this variation in the prevalence of infection in different age groups in cattle is difficult to explain but it might be due to an age related variation in resistance to disease and grazing habit (Okafor et al., 1988).

Sex related prevalence rate: The prevalence of paramphistomiasis in female animals was $59.5 \%$ and in male animals was $45 \%$ and the difference between males and females significant $(P<0.05)$. Saifuzzaman (1996) reported that the percentage of paraphistomum infection in male and female cattle was $45.5 \%$ and $55.6 \%$, respectively. The higher percentage of infection in the females may be due to the alteration in the physiological condition of the animals during pregnancy and lactation (production activity) and also the lack of feed supplement for production, which may lead to the lowering of body resistance of the females. 
Seasonal effect on prevalence of paraphistomiasis in cattle: The prevalence of pramamphistome infection in cattle during the rainy, winter and summer seasons were $60.8 \%, 48.3 \%$ and $50 \%$, respectively (Table 1) which were varied significantly $(\mathrm{P}<0.05)$. This result is closely related to the reports of Petkov et al. (1988); Dakshinker and Sandy (1982) and Okafor et al. (1988). However, Manna et al. (1994) reported that the highest incidence of Paramphistomiasis was in the summer season. This variation might be due to different climatic factors such as temperature, rainfall and humidity which influence the availability of intermediate host, other agro- climatic condition and ecology of the vector and host.

Feeding habit and prevalence of paramphistomiasis in cattle: The prevalence of Paramphistomiasis was higher in grazing cattle (62.5\%) than that of stallfed cattle (45.5\%); however the difference was not significant (Table 1).

Table 1. Prevalence of paramphistomiasis in three seasons in the selected areas of the Sirajgonj district with regard to breed, age and sex of the animals and feeding system

\begin{tabular}{|c|c|c|c|}
\hline Factors & $\begin{array}{c}\text { Numbers of } \\
\text { animals examined }\end{array}$ & $\begin{array}{c}\text { Percent of animals } \\
\text { infected }\end{array}$ & Odds ratio \\
\hline $\begin{array}{l}\text { Seasons* } \\
\text { i. Summer } \\
\text { ii. Rainy } \\
\text { iii. Winter }\end{array}$ & $\begin{array}{l}120 \\
120 \\
120\end{array}$ & $\begin{array}{l}50.0 \\
60.8 \\
48.3\end{array}$ & $\begin{array}{c}1.55 \\
1.66 \\
\$\end{array}$ \\
\hline $\begin{array}{l}\text { Breeds* } \\
\text { i. Crossbred } \\
\text { ii. Indigenous }\end{array}$ & $\begin{array}{l}110 \\
250\end{array}$ & $\begin{array}{l}61.8 \\
49.2\end{array}$ & $\begin{array}{c}1.67 \\
\$\end{array}$ \\
\hline $\begin{array}{l}\text { Age groups* } \\
\text { i. Growing } \\
\text { ii. Young } \\
\text { iii. Older }\end{array}$ & $\begin{array}{l}124 \\
100 \\
136\end{array}$ & $\begin{array}{l}44.4 \\
54.0 \\
60.3\end{array}$ & $\begin{array}{c}\$ \\
1.29 \\
1.94\end{array}$ \\
\hline $\begin{array}{l}\text { Sex groups* } \\
\text { i. Male } \\
\text { ii. Female }\end{array}$ & $\begin{array}{c}72 \\
119\end{array}$ & $\begin{array}{l}45.0 \\
59.5\end{array}$ & $\begin{array}{c}\$ \\
1.79\end{array}$ \\
\hline $\begin{array}{l}\text { Feeding management } \\
\text { i. Grazing } \\
\text { ii. Stall feeding }\end{array}$ & $\begin{array}{l}160 \\
200\end{array}$ & $\begin{array}{l}62.5 \\
45.5\end{array}$ & $\begin{array}{c}1.99 \\
\$\end{array}$ \\
\hline
\end{tabular}

* indicate $P$ value $<0.05$ and significantly varies each other and $\$$ indicate the base category of logistic regression

It may be concluded that the prevalence of Paramphistomum Spp. in cattle is common in Sirajgonj area on Bangladesh. Female, crossbred and older cattle were more susceptible to paramphistomum infection. From our clinical and field experiment it is observed that the disease is diagnosed throughout the year, but its prevalence is more in rainy season than that of other seasons.

\section{References}

Afazuddin, M. 1985. General incidence and therapeutic measures of parasitic diseases in cattle of saver Military Dairy Farm. M. S. Thesis. Submitted to the Department of Medicine, Bangladesh Agricultural University, Mymensigh.

Chandrasekharan, K. Radhakrishan, K. Jacob, V. and Cheeran, 1982. Efficacy of Distodin in the treatment of amphistomiasis in Indian elephants. Kerala Journal of Veterinary Science. 13: 55-58.

Dakshinker, N.P, and Sandy, M.R. 1982. Incidence of helminth in ruminants of Nasgpur region. Livestock adviser. 7: 49-50.

Faiz, M.A. 1972. Report on "Investigation in to the epidemiology of parasitic disease in East Pakistan". In: Activities on the Research sections of Directorate of Livestock Services Bangladesh.

Hosain, M.I. and Baki, M.A. 1987: Pathological studies on intestinal amphistomiasis in buffaloes. The Bangladesh Veterinarian. 4: 29-33. 
Islam, K.S.1985. Present situation of livestock and poultry diseases in Bangladesh. In: Jabbar MA (ed) Bangladesh poshusampad unnayun-Neeti O Kowshal BARC, Dhaka and ADC NY. 84-128.

Jabber, M. and Green, D.A.G. 1983. The status and potential of livestock within the context of agricultural development policy in Bangladesh. The University of wales. Aberystwyth, United Kingdom. 113.

Manna, A.K. Pramanik, S. and Mukherjee, G.S. 1994. Incidence of paramphistomiasis in west Bengal. Indian Journal of Animal Health. 33: 87-89.

Mostafa, M.G. 1989. Methods of statistics, Karim press and Publication, Dhaka, Bangladesh.

Okafor, F.C. Mbata, G. and Anosike, J. 1988. Studies on Patamphistomum cervi (Schrank, 1790) infection of ruminants in Imo state, Nigeria with special reference to the role played by Bulinus b. forskalii (Ehrenberg) in their transmission. Bulletin of Animal Health and Production in Africa. 38: 142-146.

Petkov, A. Rusev, I. Ignafov, G. Toncheva, V. and Mikhailov, Z. 1988. Epidemiological control, early chemoprophylaxis and treatment of ovine fascioliasis Veterinarnal Sbirka 86: 42-44.

Rabbani, S.M.B. 1992. Studies on the prevalence of Buffalo diseases. M S Thesis, submitted to the Department of pathology, Bangladesh Agricultural University, Mymensingh.

Rahman, M.H. and Mandal, M.H. 1983. Helminths parasites of cattle (Bos indicus) in Bangladesh. Indian Journal of Parasitology. 7:173-174.

Rahman, M.H. and Razzak, A. 1973. Incidence of helminth parasited infecting cattle. Kotwali Thana of Comilla, First Bangladesh Veterinary Conference, Agricultural University Campus, Mymensingh 25.

Sahay, M.N. Sahai, B.N. Singh, S.K. 1989. Survey of paramphistome infection in bovine. Its seasonal and regional variations in the state of Bigar (India). Indian Journal of Animal Health. 28: 91-92.

Saifuzzaman, A.B.M. 1996. Incidence and seasonal variation of helminth parasites of cattle of Chandina Thana in Comilla district. MS Thesis. Submitted to the Department of parasitology, Bangladesh Agricultural University, Mymensingh.

Soulsby, E.J.L. 1982. Helminths, Arthropods and protozoa of Domesticated Animals. $7^{\text {th }}$ edn. ELBS, Bailliere, Tendal 70-71. 